\title{
ВПЛИВ ДЕФІЦТУ ЙОДУ НА СТАН ЩИТОПОДІБНОЇ ЗАЛОЗИ ТА РОЛЬ МЕДИЧНОЇ СЕСТРИ У ПРОФІЛАКТИЦІ ЗАХВОРЮВАНЬ, СПРИЧИНЕНИХ НЕДОСТАТНІСТЮ ДАНОГО ЕЛЕМЕНТА
}

\author{
Х. І. Козак, Л. В. Сенюк
}

Чортківський державний медичний коледж

\footnotetext{
У статті проаналізовано вміст йоду в навколишньому середовищі, захворювання, які виникають внаслідок його дефіциту, а також розглянуто профілактику захворювань.
}

\section{IMPACT OF IODINE DEFICIENCY ON THE STATE OF THYROID GLAND AND NURSES ROLE IN PREVENTION OF DISEASES, CAUSED BY LACK OF THIS ELEMENT}

\author{
H. I. Kozak, L. V. Seniuk \\ Chortkiv State Medical college
}

The article analyzes the content of iodine in the environment, the diseases, coused by its deficit, and their prevention.

Вступ. Серед актуальних проблем сучасної медицини особливе місце займає зростання патології щитоподібної залози, яке зумовлене складною екологічною ситуацією в деяких регіонах України. Загальновідомо, що рівень здоров'я населення перебуває в прямій залежності від стану навколишнього середовища, а ендокринна система, має найбільш високу чутливість до токсичних екзогенних впливів. Завдання ліквідації йододефіцитних захворювань у всьому світі визнано актуальним у медичному та соціально-економічному аспекті, оскільки ці захворювання впливають на стан здоров'я населення, освітній та професійний потенціал суспільства [9].

Основна частина. Одним із найбільш необхідних і важливих елементів, що сприяе нормальному росту і розвитку людського організму, є йод. Він поступає в організм у надзвичайно малих дозах, але відіграє важливу роль у процесі життєдіяльності людського організму. Близько $30 \%$ населення земної кулі проживають у районах із йодним дефіцитом. У зв'язку з дефіцитом йоду порушується біосинтез тироксину, трийодотироніну і тетрайодотироніну - гормонів щитоподібної залози, розвивається компенсаторне збільшення ціеї ендокринної залози [1].

(C) Х. І. Козак, Л. В. Сенюк, 2015
Йододефіцитними захворюваннями, за визначенням Всесвітньої організації охорони здоров'я, є всі патологічні стани, що розвиваються у популяції в результаті йодного дефіциту, яким можна запобігти при нормалізації споживання йоду [2].

Йод виявлений в незначних кількостях в ґрунті, повітрі та воді, а також концентруеться і в мулі. Розсіяний йод вилуговуеться природними водами з магматичних гірських порід і концентруеться організмами, наприклад, водоростями.

Джерелами надходження йоду в поверхневі води $є$ атмосферні опади, води нафтових родовищ і стічні води деяких галузей хімічної й фармацевтичної промисловості. Вміст йоду у дощовій воді складає 1-5 мг/л; у прісній воді 1 мкг/л; в морській воді йоду значно більше. У приморських областях кількість йоду в $1 \mathrm{~m}^{3}$ повітря може досягати 50 мкг, в континентальних і гірських становить 1 або навіть 0,2 мкг. Поглинання йоду рослинами залежить від вмісту в ґрунтах його сполук і від виду рослин.

Тривалий час вважалось, що основним наслідком дефіциту йоду е збільшення щитоподібної залози, однак саме по собі воно не є найгіршим наслідком дефіциту йоду. Дефіцит йоду в організмі веде до зниження утворення ти- 
реоїдних гормонів, оскільки синтез гормонів відбувається шляхом йодування тирозину і подальшої конденсації (з'єднання) таких двох молекул 3 утворенням три- і тетрайодотироніну (тироксину), які і $є$ власне гормонами. Однак у клітинах щитоподібної залози вони пов'язані з білком глобуліном (йодотиреоглобуліном) і перебуває в неактивному стані. У міру необхідності цей комплекс розпадається, гормони стають активні, надходять в кров, органи і тканини, де і проявляють свою дію. Іх дія в основному спрямована на посилення процесів біологічного окиснення, збільшення споживання кисню, регуляцію обміну жиру і води, диференціювання розвитку тканин.

До захворювань, причиною яких є дефіцит в організмі йоду, належать:

- дифузний еутиреоїдний (нетоксичний) зоб;

- вузловий еутиреоїдний (колоїдний) зоб;

- тиреотоксикоз (тиреотоксична аденома);

- йододефіцитний гіпотиреоз (за різного вираження дефіциту йоду) [2].

Фізіологічна добова потреба в йоді для різних груп людей різна і залежить від віку і фізіологічного стану організму. Для дітей молодшого віку (від 2 до 6 років) - 90 мкг/добу; для дітей від 7 до 12 років - 120 мкг/добу; молоді люди і дорослі потребують 150 мкг/добу; вагітні жінки і ті, які годують груддю - 200 мкг/добу і люди похилого віку потребують 100 мкг/добу [4].

За все життя людина споживає всього 3-5 г йоду. Про етіологічну роль дефіциту йоду в розвитку ендемічного зобу свідчить збіг районів розповсюдження зобу з нестачею йоду в цих місцевостях, ефективності йодної профілактики і виявлення особливостей метаболізму в хворих на ендемічний зоб.

Головною причиною виникнення ендемічного зобу є нестача йоду в навколишньому середовищі. Забезпечення населення необхідною кількістю йоду можливе або шляхом зміни характеру харчування, або за допомогою додаткового приймання препаратів йоду. Такий підхід покладений в основу існуючих методів йодної профілактики:

- індивідуальна;

- групова;

- масова.

Індивідуальна і масова профілактика перш за все пов'язана із ліквідацією дефіциту йоду в продуктах харчування [6].

Найбільш ефективним і економічним методом усунення дефіциту йоду є масова профілактика можливість корекції йодного дефіциту за допомогою харчових продуктів, які є носіями високих концентрацій йоду. До них належать:
- йодована сіль, йодована вода, йодоване масло, збагачені йодом продукти (хліб, кондитерські вироби, м'ясні продукти, молоко, кефір та інші молочні продукти;

- багаті на йод продукти моря: молюски (устриці, мідії, морські гребінці, кальмари), голкошкірі (трепанги, голотурії), ракоподібні (краби, креветки, лангусти, омари), морські водорості (відомо більше 70 видів їстівних водоростей);

- спеціальні продукти для вагітних та жінок, які годують груддю (молочні напої або каші, збагачені йодом, адаптовані молочні суміші для дітей, насичені йодом) [5].

Йодування солі $є$ найуніверсальнішим засобом йодопрофілактики за рахунок того, що:

- ії споживають практично всі;

- це дешевий продукт, який доступний всім групам населення;

- сіль споживають у невеликій кількості, тому її можна збагатити більшою кількістю йоду, ніж інші продукти;

- вартість йодованої солі практично не відрізняеться від вартості нейодованої.

Ії йодують на сольових рудниках із розрахунку 40 мг на кожен кілограм солі приблизно вноситься йодиду калію (йодат більш стійкий, ніж йодид), тобто в 1 г йодованої солі міститься 40 мкг йоду. Йодована сіль - це не якась медичнохарчова добавка, це звичайний продукт харчування, який вживають всі [3].

Дослідженнями доведено, що за 6 місяців йодована сіль у герметичній упаковці втрачає 30 \% йоду, в розірваній - 80 \% (в літні місяці $90 \%$ ).

Останнім часом широко використовують метод йодування води. Використання цієї води дає позитивний результат, сприяє ліквідації йодної недостатності в організмі.

В останні роки у різних країнах використовують метод йодної профілактики зобу за допомогою йодування олії. 3 ціею метою застосовують йодовану олію з насіння маку, яка повільно вивільняе йодид. Також йодують кондитерські вироби за допомогою морської капусти.

Досить широко впроваджується внесення мікродобрив у ґрунт з домішками йоду, міді, марганцю, кобальту, завдяки яким овочі насичуються йодом вдвічі і навіть втричі краще.

Встановлено, що додаткове регулярне споживання 100-150 мкг йоду із збагаченими продуктами харчування приводить до суттєвого (на 50-60\%) і достовірного зниження частоти збільшення щитоподібної залози в дітей шкільного віку протягом 6-9 місяців від початку проведення йодної профілактики [7].

Групова профілактика передбачає застосування препаратів йоду в організованих колекти- 
вах: дитячих садках, школах, навчальних закладах. Контроль за профілактикою здійснюють спеціалісти-медики. Ряд спеціалістів дотримується думки, що групова профілактика повинна випереджати масову. Бажано розпочинати програми йодної профілактики 3 введення солей йоду в їжу в дитячих садках, у шкільні сніданки [8].

Індивідуальну профілактикупроводять серед неорганізованого населення та за спеціальними медичними показаннями. До кагорти таких можна віднести вагітних, жінок, які годують, немовлят, які перебувають на штучному вигодовуванні, маленьких дітей та дітей, які виховуються в домашніх умовах, осіб 3 різними захворюваннями щитоподібної залози, а також населення, яке проживає в ендемічній зоні. Для індивідуальної профілактики можуть використовуватися як йодовані продукти харчування, так і препарати йоду.

\section{ЛІТЕРАТУРА}

1. Боднар П. М. Йододефіцитні розлади-актуальна медико-соціальна проблема / П. М. Боднар// Лікарська справа. - 2001. - № 3. - С. 8-10.

2. Боднар П. М. Ендокринологія / П. М. Боднар. Вінниця : Нова книга, 2007. - 344 с.

3. Герасимов Г. А. Всеобщее йодирование пищевой поваренной соли для профилактики йододефицитных заболеваний: преимущества значительно превышают риск / Г. А. Герасимов / / Проблемы эндокринол. 2001. - № 3. - С. 22-26.

4. Гульчій М. Г. Йод: скількийого потребує організм, або про причини захворювань щитоподібної залози / М.Г.Гүльчій / / Ваше здоров'я. - 2001. -№ 19. - С. 3-18.

5. Йододефіцит серед населення тайого подолання / С. Т. Омельчук, С. І. Гаркавий, Н. Т. Музичук, А. Я. Кобзар / / Науковий вісник національного медич-
Найефективнішим засобом індивідуальної йодної профілактики є приймання препаратів йодиду калію: «Йодид-100» i «Йодид-200». Отже, йдеться про дозоване щоденне споживання йоду. Тобто при прийманні цього препарату точно відомо, скільки йоду, не більше і не менше, надійшло в організм.

Необхідно врахувати, що незалежно від методів профілактики зобу йод найбільш оптимально засвоюеться при достатньому вмісті в раціоні білка, заліза, цинку, міді, вітамінів А та Е.

Висновок. Ми, як медичні працівники повинні активно інформувати населення про захворювання, що виникають внаслідок недостатності надходження йоду в організм людини, а також про всі види профілактики даних захворювань. Вміння медичного працівника ефективно донести до паціентів методи профілактики йододефіцитних захворювань - запорука здорової нації.

ного університету імені О. О. Богомольця. - 2006. № 4. - С. 134-138.

6. Паньків В. І. Йододефіцитні захворювання: діагностика, профілактика, лікування / В. І. Паньків / / Проблеми ендокринноїпатології. - 2002. - № 2. - С. 75-86.

7. Тимченко А. М. Ендемічний зоб (обговорення консенсусу ташляхи вирішення проблеми) / А. М.Тимченко / / Міжнародний ендокринологічний журнал. 2006. - № 3 (5). - С. 9-12.

8. Тронько М. Д. Дифузний зоб: діагностика та лікування / М. Д. Тронько, В.І.Кравченко // Ендокринологія. - 1999. - №1 . - C.4-11.

9. Assessment of the lodine Deficiency Disorders and monitoring their elimination: a gide for programme managers. - 2nd ed. - Geneva: WHO/Euro/NUT/, 2001. - P. 1-107. 